ETHEL MATALA DE MAZZA

\title{
Romantic politics and society
}

\section{Tendencies of an age}

'Die Französische Revolution, Fichtes Wissenschaftslehre, und Goethes Meister sind die größten Tendenzen des Zeitalters' ('The French Revolution, Fichte's Theory of Knowledge, and Goethe's Wilhelm Meister are the three greatest tendencies of the age'), Friedrich Schlegel remarks in a famous Fragment (No. 216) published in Athenaeum in 1798 . According to Schlegel, it was but a small step from the mass revolt in France to the treatise of a German professor and then to the latest novel of a bestselling author. But in this unusual juxtaposition of events, which followed both on and from each other, the Revolution, en route to Germany, went politically adrift. The event was repeated on paper, in books designed to educate readers rather than in actions dethroning monarchs. These writings, as we shall see, shifted the uprising from politics to philosophy and literature.

Many authors of the Romantic generation - poets and philosophers as well as publishers, literary critics and political thinkers - followed the same path around I 800 . The events in France, which most of them, like Schlegel himself, knew only at second hand through newspapers, books and word of mouth, provided both an impetus and an object of criticism for their political thought. Sobered by the increasingly radical 'tendencies' of the revolutionaries and the dramatic escalation of the Revolution, the authors engaged in a heated debate about the notions of state and society, nation and Volk. In theoretical sketches and practical experiments, they developed models designed to be understood not only as more convincing alternatives to the French revolutionary state, but also as counter-concepts drawing their social meaning from home-grown traditions.

All these debates turned on the question of how Germans might conceive an authentic national culture of their own, precisely because the political situation in Germany at the close of the eighteenth century was hardly comparable to the French. A German state, in the sense of a homogeneous, 
centralised political entity, did not exist. What remained of the 'Heiliges Römisches Reich deutscher Nation' ('Holy Roman Empire of the German Nation') was dispersed over a fragmented landscape of larger and smaller territories, some of which barely qualified as states. But this made the demands arising from the Romantics' reflections all the more ambitious. On the one hand they formulated political ideals and social fictions in the utopian 'as if' mode of literature. On the other hand they intended their texts to perform pragmatically as interventions that would produce the desired community by literary means, and, through a dialogue with the reading public, generate the 'We' in whose name they pre-emptively spoke. The social models of the Romantics were aesthetic constructs in the most precise sense: they grounded their postulate of togetherness on the imaginative 'evidence' of aesthetic experience.

The most important of these constructs will be discussed in this chapter, in which it will become apparent that shifts in emphasis occurred as time passed. While the earlier conceptions insisted on the importance of explicit dialogue and communication, the later ones emphasised a sense of agreement, a 'feeling' of communal identity. Where the earlier, anticipatory models of togetherness - 'a "Fragment aus der Zukunft"' ('Fragment of the future'),' as Schlegel called them - necessarily remained ideas and projections aiming at innovation, the later ones were devoted to the (re-)construction of a buried past.

\section{Critique of the existing order}

In the last decade of the eighteenth century, the German Romantics were neither the first nor the only thinkers to distance themselves critically from the French Revolution. In 1790, soon after the outbreak of the Revolution, Edmund Burke's polemical Reflections on the Revolution in France harshly condemned the French monarchy's destruction. His apology for the Ancien Régime insists not only on the need for continuity in politics but also on the indispensability of a culture of beautiful illusions. In a bygone 'age of chivalry', recalls Burke, virtues such as dignity, noble-mindedness and 'subordination of the heart' would compensate for the dependencies and hierarchies of the time. He contrasts this heart-warming 'drapery' of gallantries with the social coldness of a rationality that recognises only stark formal obligation and the rigour of law. He concludes that reason alone has no binding force. Its principles cannot produce any emotional bonds - either with one's neighbour or with one's nation. A state that lacks aesthetic charm and 'pleasing illusions's cannot win over its citizens; it must enforce respect; it must compel obedience by imposing obligations on its citizens, by monitoring, prosecuting, punishing and - at worst - eliminating them.
When Burke's Reflections appeared in England, they were ahead of their time: there were as yet few signs of the murderous fervour with which the Revolution would overwhelm France. Hence the determination to bring reason to political fruition and ground the state in a constitution aroused great sympathy for the French revolutionaries in Germany, particularly among those writers and philosophers who would later criticise the Revolution. Both Johann Gottlieb Fichte and Friedrich Schlegel composed passionate defences of the Revolution in this phase. But with the translation of Burke's Reflections in 1793 , German enthusiasm became ambivalence. In the meantime, events in France had unfolded rapidly. As the Jacobin Terror turned on enemies within the republic, the new state revealed the despotic side of its rationality, a move that made the Romantics receptive to Burke's case. They reacted to the totalitarianism of the rule of law with a political critique that cast fundamental doubts on the cohesive power of law and the social contract and called for less rigid forms of social integration.

Liberal opinions voiced in the 1770 s by Freemasons and Illuminati with the aim of 'counteracting the inevitable evils of the [absolutist] state's - albeit without undermining the existing order as such - thereby acquired a new tenor. Some thinkers went as far as to reject any monopoly of governance, monarchic or republican, and thus questioned the very idea of a state. Fichte, in his Vorlesungen über die Bestimmung des Gelehrten ( 1794 ; Lectures on the Destiny of the Scholar), defines the state's sole purpose to be the preparation of a 'vollkommere ... Gesellschaft' ('perfect society') which would 'render governance superfluous'. ${ }^{4}$ Schiller, in his Über die ästhetische Erziehung des Menschen (1795; On the Aesthetic Education of Humankind), outline a cultural programme that would mitigate the 'Uhrwerk' ('mechanism') o the modern state, which has become 'a stranger to its citizens'.' The so-called Ältestes Systemprogramm des deutschen Idealismus ( 1797 ; Earliest System Programme of German Idealism), a collaborative manifesto (probably) by Hegel, Schelling and Hölderlin, demands that the 'whole wretched human artifact of state, constitution, regime, legal system' be dismantled 'bis auf die Haut' ('stripped to the skin'). ${ }^{6}$

Significantly, at this early point in the Romantic discourse, the 'Other' of the state was exposed through the metaphorical recognition of a 'naked', carnal substrate, which revealed the nature of the body politic under a different aspect. Henceforth Romantic conceptions of society consistently emphasised this metaphor. In particular, they propagated the notion of the state as a body that conserved the fabric of society and could best be grasped with what had previously seemed primitive instruments of cognition: feelings and reflexes, passions and inclinations. 
The tradition of the body politic

Since Aristotle drew an analogy between polis (polity) and soma (body) in his Politics, the 'body politic' has been a socio-philosophical topos in Western thought. The image of the congregation as a spiritual body and as a community in Christ dates back to St Paul. His model - conceiving of the ecclesia (church) as a mystical body of Christ uniting the multitude of believers - became the principle of both the institutional history of the Catholic Church and the theological foundations of secular law in the Middle Ages. Following the doctrine that evolved from the concept of the body of Christ, English jurists ascribed to the king two bodies: one 'natural' and mortal, the other 'mystical' and immortal: the second guaranteed the eternity of royal authority.' Similarly, early modern political philosophy developed an image of the state that transcended its subjects as an 'artificial man' and transformed them into a unity by incorporating them in the body politic of the Leviathan. ${ }^{8}$

However, the social models of the Romantics modified this basic paradigm. Instead of considering the body politic as the product of a legal construct - a contract of submission, for instance, as Hobbes presumed they saw it as the premise of all social interaction. They were interested in the physical body as an elemental and ever-present substance from which society drew its vital energies and out of which its natural bonds grew, independently of any individual action. The Romantics defended such the ories by citing the latest discoveries in medical-scientific knowledge of the human body. In the last third of the eighteenth century, the humanities and natural philosophies developed a new understanding of the body, which was no longer regarded as a sort of hydraulic machine set in motion by the ebb and flow of 'humours', but as a living organism governed endogenously by its own neuro-sensory system. Its life processes should no longer be described in terms of mechanistic principles of action and reaction, matter and motion. Rather, they manifested themselves as the results of physiological processes governed from within by a complex rhythm of stimulus and (sensitive or irritable) response. To the extent that the nervous system acquired a central role as the mediating instance between the brain and other organs and ensured intra-corporeal communication between the physical and the intellectual, the received categorical distinction of body and soul was abandoned. The border established in the old model berween spiritual and corporeal realms became porous, and emphasis shifted from their differences to their reciprocal influence. Thus it became plausible also to think of the forms of intersubjective communication as extensions of this kind of organic interplay. Stimulating conversations, inspiring ideas, infectious enthusiasms, electrifying impulses could be seen as analogies of nervous stimulus-response reflexes. The old Christian notion of a collective corporeal unity gained new relevance. The Romantics hoped to make people experience this bodily oneness of the social or political community through the senses, and they chose aesthetic discourse as one of their chief means to achieve that goal.

\section{Reforming society from within}

One of the earliest and most pertinent examples of this is Glauben und Liebe (1798; Faith and Love), a marvellously intricate collection of aphorisms by Friedrich von Hardenberg (Novalis). On the accession of a new, young and widely admired King and Queen of Prussia Hardenberg challenges the royal pair to embody his Romantic ideal of government. Hence, rather than plead for the destruction of the existing state (a kind of rationalised monarchy), he advocates a political reform from within the given structure designed to create a quite new state with no significant distinction of public and private, individual and polity, reality and poesy, indeed, even monarchy and republic. In this, so-called 'poetic state' all relationships will be founded in the deepest emotional bond of love (marital and parental love, the rulers' love of their subjects, the subjects' love of their rulers). This will guarantee the intimate and enduring interconnectedness of individual and collective in every dimension, so that the ideal community is manifest in every real relationship in the state. Thus Hardenberg advances a programme to (re) generate the Prussian body politic by medical analogy, through the most diverse communicative 'stimulations' between centre and parts of a body he sees as disjointed and dysfunctional. Apart from concrete measures, such as improving social hygiene and accelerating the flow of capital into concrete projects, this programme is thus also intended to be implemented pragmatically by the rhetorical functioning of the lyric aphorisms themselves. These insist at the level of content on a wholly novel representative role of the royal couple King Frederick William III and Queen Luisa, not as absolute monarchs by divine right or paper contract, but as the absolute incarnation of divine love - of each other, and of their subjects. At the level of form, the invocation of this ideal is couched in a self-consciously indeterminate 'mystischer Ausdruck' ('mystical expression'), which is cunningly designed to serve as 'Gedankenreiz' ('intellectual stimulus'), provoke the creative intellect of the reader to (re)construct in himself what is merely implied, and so finally, in this indirect way, arouse 'lebhafteste Regungen' ('liveliest stirrings') of love and loyalty for the absolute love concealed in the 'mystical expression'. Thus the ideal is aesthetically made present and realized in each 
individual. In the royal pair - who paradoxically embody bourgeois virtues and values par excellence - every citizen (not subject) is empowered to recognise and love the ideal self-image.

Not for nothing did Hardenberg applaud Burke's Reflections as a 'revoluzionäres Buch gegen die Revoluzion' ('revolutionary book against the Revolution')..$^{\circ}$ His aphorisms take the philosopher's appeal at its word and seek the political in beauty - in this case the beauty of the royal familial idyll - in order to move the heart and exploit the cohesive power of shared emotion. Strange as the appeal to 'stimulus' may seem today, Hardenberg's highly original, aesthetic-rhetorical move is based on solid knowledge and creative application of contemporary physiological science - in particular the theory of the then famous Scottish neuropathologist John Brown, who constructed his diagnostic model of health and ill-health on the notion of equilibrium in the body between stimulus and response through (active) irritability or (passive) sensation. Hardenberg's therapy of poetic stimulation, prescribed for a social body diagnosed by him as suffering from the lack of 'excitability' (Brown), aims at promoting harmony among the loving citizens by increasing their capacity actively to respond. Once this equilibrium is attained, the 'Buchstabe' ('letter') of the 'constitution' is obsolete; Prussia can spontaneously secure its political togetherness without further written guarantees; the 'papierne[r] Kitt' ('papier mâché')" dispensed with, and the rule of the merely arbitrary signs of a paper document - an empire to which, in the end, even literature itself belongs - will
be over.

Friedrich Schleiermacher's Versuch einer Theorie des geselligen Betragens (1799; Essay on a Theory of Social Conduct) offers a different model, founded on conversational exchange. After a discussion of aesthetic topics it develops a theory of socialisation that focuses not on the state, but on the social 'circle', which, as a third space between the public and private spheres, is characteristically free of formalities and restrictions. Where labour binds the communicative spirit to external ends, and family restricts free communication to a handful of people, the open, noninstrumental sphere of sociality - a sphere 'not dominated by any law' allows the individual to abandon himself to the 'freie[s] Spiel' ('free play') of forces. Of course, sociality is based on the experience of difference in the conflict between contrary positions. For Schleiermacher, conversational exchange provides just such an experience of difference, insofar as speakers continually encounter new asymmetries of self and other. But as long as speakers engage in the process of discursive mediation, no shared outcome or final agreement is needed to make their communication socially productive. On the contrary: the more diverse the participants and opinions are, the more intensive their negotiation of differences can be 'Reciprocity' ('Wechselwirkung') ${ }^{12}$ is Schleiermacher's term for a dynamic of discussion that can be regarded as a model of social self-regulation, because the unceasing hermeneutic commitment creates a loose yet foundational commonality between speakers. What makes Schleiermacher's theory challenging is that it presupposes disagreement as a premise of social interaction and turns the processing of differences into a practice of integration. Unanimity, in this sense, would mean paradoxically a tearing apart of social bonds.

Another Utopian vision, realised through written exchange rather than dialogue, is developed in Friedrich Schlegel's novel Lucinde (1799). Lucinde unfolds this model - partly by means of recognisable biographical parallels between the eponymous heroine and Dorothea Veit, Schlegel's own lover - from the happy union of the sexes. At its narrative centre this union constitutes, first, the goal of an embedded Bildungsroman. Julius, a dilettante painter, undergoes 'Lehrjahre der Männlichkeit' (an 'apprenticeship in manhood') in preparation for encountering his erotic and intellectual equal in Lucinde. However, the identity-in-difference of the loving couple is also mirrored in the highly diverse short prose pieces that ring the central Bildungsroman. The union of sexual opposites resonates in the union of different textual genres. The novel Lucinde can therefore be read as both an erotic and an aesthetic manifesto. It also, however, provides a miniature example of a vast project Schlegel had sketched out a year before in his Ideen Fragments: the 'absolute book'. This book, also called the 'new Bible', is theorised by Schlegel as a book of books, one in which 'alle Bücher' are 'nur Ein Buch' ('all books are simply One Book'), the totality of what is printed and possible. This notion of the new Bible or 'ewig werdendes Buch' ('eternally nascent book' $)^{13}$ attracted Schlegel not only through its unity-indiversity but also its ability to catalyse the formation of a new community - of writers and readers. But if Lucinde, with its synthesis of many and one, represents a poetic matrix of the 'unendliches Buch' ('infinite book'), its fertility in the reproduction of literature still had to be proven.

Each of these models - Hardenberg's poetic state, Schleiermacher's sociality and Schlegel's new Bible -imagines an intensive form of reciprocal interaction which is catalysed and governed by literature. Each also, let us note, exploits despite its visionary character an empirical model from which it derives its Utopian ideal. Hardenberg conceives of his poetic state, in a comparatively conventional manner, as a multiplicity of bourgeois marriages. Schleiermacher and Schlegel have in mind the more Bohemian Jena circle to 
which they - and Hardenberg - belonged. The principle of collective writing ('sympoesy') and collective philosophising ('symphilosophy'), as well as the erotic libertinism of some of the members, left their traces in the concept of a society engaged in free communication.

In reality, the sociality of the Jena circle lasted only a year (I798). Even in this small group the interplay designed to guarantee the constant selfregeneration of sociality proved highly unstable. Nonetheless, their experiment inspired several other literary collectives. One of the best-known is the so-called 'Serapion Brotherhood', a fraternity of intellectuals centred on E. T. A. Hoffmann in legitimist Restoration Berlin after 1816 . In the work bearing that name, published by Hoffmann I8I9-2I, the anthology of stories is framed by the provocative and provoked exchanges of the group. However, for political Romanticism the Heidelberg circle, which comprised Achim von Arnim, Bettine von Arnim, Clemens Brentano, Sophie Mereau, Karoline von Günderrode, Joseph von Eichendorff, Joseph Görres and Friedrich Creuzer, was more important. Apart from literary concerns, the Heidelberg Romantics shared an interest in historical studies and in the collecting of forgotten stories, songs, fairy tales and myths. In the early nineteenth century, they exemplified the widespread German desire for national and cultural reassurance, which grew in proportion as German political circumstances worsened, and Napoleon extended his hegemony over Europe. Many writers felt moved to engage in patriotic declarations and initiatives. The political thought of Romantics now focused specifically on questions of national identity.

\section{The invention of tradition}

Initially, the search for identity turned to the past. In I 806 and I 808 , Achim von Arnim and Clemens Brentano published a collection of half-forgotten, half-invented folk-songs entitled Des Knaben Wunderhorn (The Boy's Magic Horn). In 1807 Joseph Görres's survey Die teutschen Volksbücher (German Chapbooks) appeared. There followed in I8I2 and I8Is the Grimm Brothers' Kinder und Hausmärchen (Fairy Tales for Household and Nursery). With a little help from the modern imagination, all these projects sought to rescue a threatened oral culture. The preservation of a native culture thus went hand in hand with its (re)invention. The intention was to recover an originary common property that could be claimed as the cultural inheritance of the nation and thus as a guarantee of national identity. 'Once we have acknowledged that an inner spirit lives ... in every class', Joseph Görres wrote in the introduction to his Volksbücher, 'we will also become more familiar with the idea that the lowest regions can also mean, and count for, something in the collective world of thought, and that the great Literary State has a House of Commons in which the nation directly represents itself'. Unlike the writings of named authors, the stories and songs of the oral tradition belonged to everyone and no one. The people, among whom they circulated, were the origin, reservoir and vehicle of transmission of a poetic treasure in which - supposedly - an archaic dawn of culture was preserved. For political Romanticism, this mobilisation of a Volk and its originary 'Stimme' ('voice') was significant, since these German authors appropriated the term claimed by the French revolutionaries for their new sovereign but endowed it with a different meaning. In place of a politically empowered people, the source of identity appeared in the form of a poetically productive Volk.

The early Romantic social Utopias were not interested in this Volk. In projecting their ideals of revitalising intellectual stimuli, free sociality and the infinite book, they assumed a standard of education that few could reach in the early nineteenth century. This standard was now abandoned or questioned. As Arnim's essay 'Von Volksliedern' ('On Folk-songs') in the Wunderhorn argues, education, as the privilege of the elite, had lost political credit. The voice whose songs, poems and stories the Heidelberg Romantics recorded belonged to people from the simplest, mostly illiterate social strata. Such people, as Görres said, live 'the spreading, dreamlike, somnolent life of a plant; their mind is cultivated only seldom and modestly, and can only bask in the rays of the higher universal forces; while its flowers draw everything down into the roots beneath the earth, where they produce edible tubers which, like potatoes, never see the sunlight'. ${ }^{14}$

The philologist Jacob Grimm and the jurist Friedrich Carl von Savigny emphasise that the authentically German legal traditions also have their roots in this poetic soil. Starting from the proposition that 'law and poetry grow up together from a single bed', Grimm, in his essay 'Von der Poesie im Recht' (I8I5; 'On the Poesy in Law'), outlines a programme for the historical study of law founded primarily on language - vocabulary, metaphors, rhetorical formulas and idiomatic expressions - with the aim of unearthing the oldest legal norms embedded in it. He regards above all analogies as important indicators of the close relationship between early law and poetry, for instance when he demonstrates that old German used 'for the very same words or names the ideas of law and of poetry' (e.g. calling both the judge and the poet a 'finder'); or when he cites the frequency of alliterations and periods structured in triads in medieval legal formulations to prove that legal norms were, initially, 'nichts anders wie sagen und geschichten, metrisch in lieder gebunden' ('metrically bound in songs, not unlike sagas and stories'). In these features Grimm also claims to discern an intrinsically 
poetic quality of German legal talk, manifest both in its inclination towards almost-pleonastic 'tautology',"s - more accurately, the figure of hendiadys (as in German 'Haus und Hof, 'Kind und Kegel', 'Mann und Maus' - or English 'to have and to hold', 'sound and fury', 'rain and weather') - and in a pristine 'sensual element'16 of German legal maxims, symbols and rituals, whose power lies 'not in dead books and formulas', but 'in the mouth and the heart'. ${ }^{17}$ The critical distance of folk-song collectors from the achievements of high culture resurfaces in Grimm's research into legal history in the form of an aversion to the effete written style of codification - a late echo of Burke - as well as an example of the general distaste for the dominance of Roman over German law.

In Savigny's epoch-making Vom Beruf unsrer Zeit für Gesetzgebung und Rechtswissenschaft (I8I4; On the Vocation of our Age for Legislation and Jurisprudence), a treatise that inspired Grimm, the resistance to foreign domination finds a new opponent in the Code Napoléon that had been introduced in virtually all the German states. Like Grimm, Savigny argues for a return to history as source of authority. In a detailed response to the proposal of his colleague Anton Thibaut that a common code of law for the German states be introduced, Savigny identifies the double risk that such a construct would hold: mechanising the practice of law - which could be 'overwhelmed by mere texts' - and weakening the constitution's authority. Authority, he continues, derives from something not made by men, but which has grown and, like religion, is born of spirit. Thus Savigny appeals to the German sensibility for the 'natural development of communities and constitutions'; he insists on the 'indissoluble organic connection of generations and ages; between which only development, and no absolute end or beginning, is conceivable'; and he recommends that jurisprudence follow a 'strenge historische Methode' ('strict historical method') that would trace every given matter to its roots in order to 'discover an organic principle, whereby that which still has life may be separated from that which has died and only belongs to history'. While not using the term Volksgeist (national spirit) - which Savigny employs only much later, in his System des heutigen römischen Rechts (I 840; System of Contemporary Roman Law) - the early essay on the Beruf unsrer Zeit already assumes popular belief, custom and habit to be the only legitimate sources of law. The reconstruction of these customs and beliefs is delegated to meticulous philological work on 'material at hand'. For the constitution to become 'common to the whole nation', jurisprudence should not only transmit 'den ganzen Reichthum der vergangenen Geschlechter' ('the whole intellectual wealth of past generations'), but also impart to juridical language the 'frische, ursprüngliche Lebenskraft' ('freshness and primitive vigour') ${ }^{18}$ which will preserve it from death in a grave of letters.

\section{Defensive measures}

The historical search for traces of the originary Volk and its spirit distinguishes the juridical and poetic enterprises of these writers from the numerous contributions of philosophers and poets such as Johann Gottlieb Fichte, Heinrich von Kleist and Adam Müller who championed the Prussian cause. The debates they joined were about urgent defensive measures rather than the archaeology of a national culture. After the heavy defeat inflicted by Napoleon's troops on the Prussian army at Jena-Auerstedt in I806, ministers and generals hastened to consolidate the Prussian state, which was now under Napoleon's rule, from within. Their military reforms were followed by reforms in administration, education and civil rights. In speeches, plays and the manifestos of newly founded literary associations, the authors of this period echoed these efforts. At the same time they developed highly emphatic ideas of the community of the Volk, in particular of the sacrifices it might legitimately demand and the wars that were to be fought in its name.

Kleist's play Die Hermannsschlacht (1809; The Battle of Teutoburg Forest), for example, anticipates the national uprising against Napoleon. It portrays a partisan war of the colonised Germanic peoples fuelled by hatred of the colonisers, albeit a war which aimed not at the recovery of freedom, but rather at blind, raging destruction of the Roman (i.e. French) enemy. It is the 'Pflicht jedes Einzelnen' ('duty of each individual'), Kleist writes explicitly in the Katechismus der Deutschen (1808; Catechism of the Germans), 'zu den Waffen zu greifen, den Anderen ... ein Beispiel zu geben, und die Franzosen, wo sie angetroffen werden mögen, zu erschlagen' ('to take up arms, to be an example ... to others, and to defeat the French wherever they can be confronted'). ${ }^{19}$ In Kleist's play the hero Hermann justifies this war of annihilation as a 'cleansing service' for the national body: 'Die ganze Brut, die in den Leib Germaniens / Sich eingefilzt, wie ein Insektenschwarm, / Muß durch das Schwert der Rache jetzo sterben' ('The entire brood that has infiltrated / The body of Germania like a swarm of insects / Must now perish beneath the sword of revenge'). ${ }^{20}$

In contrast, Adam Müller's Zwölf Reden über die Beredsamkeit und ihren Verfall in Deutschland (Twelve Addresses on Eloquence and its Decline in Germany) recommended a national 'Waffenübung der Seele' ('mobilisation of the soul'). ${ }^{21}$ These speeches self-consciously rely on the force of sublime 
oratory to elevate their listeners and readers. However, while Fichte, in his patriotic Reden an die deutsche Nation (1807-8; Addresses to the German Nation), demands the extension of 'die neue Bildung' 'an alles ohne Ausnahme, was deutsch ist ..., so daß dieselbe nicht als Bildung eines besonderen Stands, so daß sie Bildung der Nation schlechthin als solcher ... werde' ('the new education to every German without exception, so that it becomes not the education of a single class, but the education of a nation'), ${ }^{22}$ Müller invokes the universal comprehensibility of the spoken words of the mother tongue and the "unmittelbare Gewalt der Töne' ('immediate power of sounds').23 Eloquence is to be as much the instrument of a 'military' as of an aesthetic education. It should produce an inner movement from which a mature 'Nationalselbstgefühl' ('national self-assurance') ${ }^{24}$ might grow, which would confront the external enemy with internal resistance.

In this way the Reden über die Beredsamkeit fulfil the demand raised by Müller in his Elemente der Staatskunst (1808-9; Elements of Statecraft). According to the theory developed here of the state as organism, the 'natur of the state' evolves in response to 'heftige Bewegungen' ('violent move ments'), which are most likely to emerge during revolution' ('violent movethe internal antagonisms of city and curing revolutions and wars. While man and wom he argument movements, the Addresses give the argument a rhetorical turn. They stress the psychological dynamics of the the statesman as a means of unleashing surges of patriotic feeling. While in Hardenberg's aphorisms poetry strives to secure the propagation of faith and love through the life of the royal couple, in Müller's Addresses it is the statesman who must function as an artist, deploying his power as an orator and infusing the masses with faith and love for an organic state. The body remains the 'nächste und schönste Muster aller Vereinigungen und Körperschaften' ('closest and most beautiful archetype of all unions and corporations') in an organic state - an 'innige, gewaltige Verbindung' ('intimate, powerful bond') 'in jedem Lebens-Moment am unmittelbarsten' ('most immediately at every moment in life').2s

\section{Political experiments}

These few examples hint at the immense spectrum of Romantic political thought. Reflections on innovative governmental politics are accompanied by those on the liberalisation of intellectual and erotic interaction, Utopian projects by patient historical research, scholarly endeavours by chauvinistic agitations and civil education programmes by military mobilisation. In their heterogeneous morphology, Romantic concepts of the state and society, nation and Volk are symptomatic of the openness and questionability of what can count as political fact, the business of everybody, res publica in the literal sense. The French Revolution made this question acute by challenging the legitimacy of the Ancien Régime and denying the king the right and monopoly of acting in the name of his subjects. Since then, not only have the foundations of all political authority been contested, but politics as such have become a topic about which there can hardly be any agreement, because its definition always depends on the variable concepts that allocate a place to it. ${ }^{26}$ Even though the Romantics distanced themselves from the constitutional form in which the revolutionaries in France framed the political, their own reflections are still marked by the innovative thought of the Revolution. The monarchy propounded by Hardenberg is different from that of the Ancien Régime, and the bestial methods with which Kleist's Hermann stokes his Germanic tribesmen's hatred of Rome are dictated by Napoleon's own armies. In inciting the Germanic peoples to fight a battle in which victory is not a matter of professional obligation but of patriotic ardour, Hermann steals the secret of the French troops' success in order to deploy it against them. The Romantics thus reproduce that for which the Revolution had set a precedent. This explains why in the case of most German Romantic authors both sympathy with and hostility to French modernity are so close together. It also explains why even the conservative approaches manifest themselves with the aplomb of innovation and why, conversely, even the most daring Utopias are infused with a longing for the return to a buried origin.

Scholars have tended to overlook this paradox in Romantic thought by separating a 'progressive' early Romanticism from a 'reactionary' late Romanticism and explicitly privileging the former. By devaluing the later Romantics modern scholars were reacting not least against the reception of the term Volk by the National Socialists, who transformed the political body into a crudely biological substance. Identified with the Germanic race, the Volk was bred, 'veredelt' ('purified') and protected against corruption by foreign 'Schädlinge' ('vermin'). The 'Religion des Blutes' ('religion of blood') proclaimed by Alfred Rosenberg as the Mythus des 20. Jahrhunderts (1930; Myth of the Twentieth Century) sought to topple the gods of the universalist religions - Catholicism and Enlightenment faith in humanity - and to replace them with the particular Germanic values that would triumph in the historical struggle for survival. ${ }^{27}$ We know the ultimate, murderous consequences of the delusion over race. The roots of such bio-political deliriums can indeed be detected in some Romantic concepts of the organic community, for example in Kleist's metaphor of - French - parasites in the body 
of Germania. Rosenberg, in his turn, places his history of the Germanic race and culture explicitly within Romantic - but also, it should be said, Classical - German traditions.

Nonetheless, it would be short-sighted to denounce the Romantic concepts of politics and society as precursors of National Socialist ideology In their search for political models beyond any possible polity, in their ceaseless efforts to escape the artificiality of legal constructs, the projects of Romantic authors are, if anything, political experiments in the laboratory of post-Revolutionary modernity, aimed at simultaneously explaining and contesting the social order. The extent to which Romantic concepts affirm the contingency of social relations - through their very faith in the integrative power of poetry, literature, ordinary speech, the performance of legal ritual, and rhetoric - was precisely described by the philosopher Carl Schmitt in his polemical critique of the movement, Politische Romantik (r9 19; Political Romanticism). ${ }^{28} \mathrm{Schmitt}$ attacked Romantic thought as lacking commitment. Later he developed a 'decisionistic' concept of the political that rejected the ambivalence of Romanticism and set out clear distinctions between friend and foe. It is not chance that Schmitt formulated his critique at a time when Germans had yet to accept the outcomes of the First World War in the Treaty of Versailles. In a Germany that only grudgingly tolerated the Weimar Republic, Romanticism experienced a new boom. Ferdinand Tönnies's sociological classic Gemeinschaft und Gesellschaft (Community and Society), which appeared for the first time in $x 887$ but was not widely read until the Weimar Republic, was perhaps the most important book to spread Romantic ideas into German political thought of the I920s. The abundance of studies, new editions and collections of Romantic literature that emerged in the years between the wars, among them Jakob Baxa's anthology Gesellschaft und Staat im Spiegel deutscher Romantik (1924; Society and State in the Mirror of German Romanticism), bears witness to this renaissance.

If political Romanticism is today again attracting attention, it owes that to the very traits Carl Schmitt condemned. Niklas Luhmann's systems theory, which derives its foundational principle from the requirement to manage contingency, paves the way for the re-emergence of the concept of the organism as 'system' or functionally differentiated structure. Other recent adaptations of - in this case early - Romantic thought can be found in models of community developed during the last few decades in France. Taking their cues from the philosophy of thinkers like Jacques Derrida, Jean-Luc Nancy and Philippe Lacoue-Labarthe, these models point towards a community in the making ('communauté désœuvrée'), ${ }^{29}$ a community that constitutes itself in its lack of unity and in the experience of its own lack of integrity.

Translated by Julia $\mathrm{Ng}$ and Ladislaus Löb

\section{NOTES}

In KFSA II, p. 198, No. 216, and p. 168 , No, 22. The translation is from Friedrich Schlegel, Dialogue on Poetry and Literary Aphorisms, trans. and eds. Ernst Behler Schlegel, Dialogue on Poetry and Literary Aphorisms, trans. and Sute University and Roman Struc (University Park and London: Pennsylvania State University Press, I968), pp. 143 and 134 . All translations, save where acknowledgement is made, are my own.

2. She Writings and Speeches of Edmund Burke, eds. L. G. Mitchell and W. B. Todd, 12 vols. (Oxford: Clarendon Press, 1989), vol. VIII, p. 128.

The from Gotthold Ephraim Lessing, 'Ernst und Falk: Gespräche für Freimaurer', in Werke, ed. H. G. Göpfert, 8 vols. (Darmstadt: Wissenschaftliche Freimaurer, See Philosophical and Buchgesellschaft, I996), vol. VII, pp. 467 and 469 . Nisbet (Cambridge: Cambridge University Theological Writings, trans. H. B. Nisbet (Car

Press, 2005), pp. 198-9 (quotation modified).

4. Johann Gottlieb Fichte, Einige Vorlesungen uber die Bestimmung des Gelehrten, in Gesamtausgabe der Bayerischen Akademie der Wissenschaften, eds. R. Lauth and H. Jacob, 34 vols. (Stuttgart and Bad Cannstatt: Frommann-Verlag, 1966), section I, vol. III, p. 37.

5. Friedrich Schiller, Úber die ästhetische Erziehung des Menschen in einer Reihe von Briefen', in Sämtliche Werke, eds. G. Fricke and H. G. Göpfert, 5 vols. von Briefen', in Sämtliche Werke, eds. G. Fricke and On trans. On the Aesthetic Education of Man, Willoughby (Oxford: Clarendon Press, 1967), p. 35 .

6. In Materialien zu Schellings philosophischen Anfängen, eds. M. Frank and G. Korellaneous Writings of G. W. F. Hegel, ed. J. Stewart (Evanston: Northwestern University Press, 2002), p. 1 IIx.

7. Ernst H. Kantorowicz, The King's Two Bodies: A Study in Mediaeval Political Theology (Princeton, N.J.: Princeton University Press, 1957).

The Matter, Forme, \& Power of A Common wealth Ecclesiasticall and Civill, ed. M. Oakeshott (Oxford: Basil Blackwell, r 960 ), p. 5 .

Friedrich von Hardenberg, 'Vermischte Bemerkungen', in NS II, p. 468, No. I22.

10. See Friedrich von Hardenberg, 'Glauben und Liebe', NS II, p. 485 , No. 3 , p. 488 , No. 17 , and p. 500 , No. 53 , and 'Blüthenstaub', NS II, p. 459 , No. 104. Translations are from Pollen and Fragments: Selected Poetry and Prose of Novalis, trans. A. Versluis (Grand Rapids, Miss.: Phanes, 1989), p. 4I, No. 89 , pp. $43-4$, No. 100, p. 47 , No. II 3 (translation modified) and p. 37 , No. 89 , No. 67 .

II. Hardenberg, 'Glauben und Liebe', p. 487 , No. I5, and p. 488 , No. 16. 
I2. See Friedrich Schleiermacher, 'Versuch einer Theorie des geselligen Betragens', in Philosophische Schriften, ed. J. Rachold (Berlin: Union Verlag, I984), pp. 4I, 47.

13. Friedrich Schlegel, 'Ideen', KFSA, II, p. 265 , No. 95.

14. Joseph Görres, 'Die teutschen Volksbücher', in Gesammelte Schriften, ed. Wilhelm Schellberg, I 8 vols. (Cologne: Gilde-Verlag, I926-), vol. III, pp. 176, I74.

I5. Jacob Grimm, 'Von der Poesie im Recht', in Kleinere Schriften, 8 vols. (Berlin: Dümmerl, I882), vol. VI, pp. I53, I58, I59.

16. See Jacob Grimm, Deutsche Rechtsalterthümer, 2 vols. (Darmstadt: Wissenschaftliche Buchgesellschaft, I955), vol. I, p. vii.

17. Ibid., p. 179.

18. Carl von Savigny, Vom Beruf unsrer Zeit für Gesetzgebung und Rechtswissenschaft (Hildesheim: Olms, I967), pp. 24, 43f., 4, II3, II7f., I6I, II3, 52. Translations are from Of the Vocation of our Age for Legislation and Jurisprudence, trans. A. Hayward (Kitchener: Batoche, 1999), pp. 25, 35, I4, $67,69,92,67,39$ (translations slightly modified).

19. Heinrich von Kleist, 'Katechismus der Deutschen', in Sämtliche Werke und Briefe, ed. H. Sembdner, 2 vols. (Munich: dtv, 1984 ), vol. II, p. 358

20. Heinrich von Kleist, Die Hermannsschlacht, in Sämtliche Werke und Briefe, vol. I, p. 593 (v. I68I-3).

21. Adam Müller, Zwölf Reden über die Beredsamkeit und ihren Verfall in Deutschland, in Kritische, ästhetische und philosophische Schriften, eds. Walter Schroeder and Werner Siebert, 2 vols. (Neuwied and Berlin: Luchterhand, 1967), vol. I, p. 372 . Translations, sometimes modified, are from Adam Müller's Twelve Lectures on Rhetoric: A Translation Followed by a Critical Essay, trans. Dennis Bormann and Elisabeth Leinfellner (Ann Arbor: University of Nebraska Press/ University Microfilms International, I978), p. I8I.

22. J. G. Fichte, Reden an die deutsche Nation, ed. R. Lauth (Hamburg: Meiner, I978), p. 24. The English is from Addresses to the German Nation, trans. R. F. Jones and G. H. Turnbull (Chicago and London: Open Court, 1922), p. I 5 .

23. Adam Müller, Reden, p. 33 I (Lectures on Rhetoric, p. $\mathrm{I}_{42}$ - translation modified).

24. Adam Müller, Ueber König Friedrich II. und die Natur, Würde und Bestimmung der preussischen Monarchie (Berlin: Sander, 1810 ), p. I7.

25. Adam Müller, Die Elemente der Staatskunst, ed. J. Baxa, 2 vols. (Jena: Fischer, I922), vol. I, pp. 5, 324 .

26. Gemeinschaften: Positionen zu einer Philosophie des Politischen, ed. J. Vogl (Frankfurt am Main: Suhrkamp, 1994); Metamorphosen des Politischen: Grundfragen politischer Einheitsbildung seit den $20 e r$ Jahren, ed. A. Göbel, (Berlin: Akademie, I995); Das Politische: Figurenlehren des sozialen Körpers nach der Romantik, eds. U. Hebekus, E. Matala de Mazza and A. Koschorke (Munich: Fink, 2003).

27. Alfred Rosenberg, Der Mythus des 20. Jahrhunderts: Eine Wertung der seelischgeistigen Gestaltenkämpfe unserer Zeit (Munich: Hoheneichen, 1930).

28. Carl Schmitt, Politische Romantik (Berlin: Duncker \& Humblot, 1998).

29. Jean-Luc Nancy, La Communauté désøuvrée (Paris: Bourgois, I986).

\section{FURTHER READING}

Anderson, Benedict, Imagined Communities: Reflections on the Origin and Spread of Nationalism, 2nd edn (London: Verso, r99I)

Balke, Friedrich, Der Staat nach seinem Ende: Die Versuchung Carl Schmitts (Munich: Fink, 1996)

Beiser Frederick C (ed.), The Early Political Writings of the German Romantics (Cambridge: Cambridge University Press, I996)

Epstein, Klaus, Die Ursprünge des Konservativismus in Deutschland: Der Ausgangspunkt: Die Herausforderung durch die Französische Revolution I770-1806 (Frankfurt and Berlin: Propyläen, 1973)

Getlef, Geselligkeit und Gesellige: Bildung, Bürgertum und bildungsbürgerliche Kultur um I 800 (Stuttgart: Metzler, 1998)

Jobstawm, Eric J., Nations and Nationalism since 1780: Programme, Myth, Reality (Cambridge: Cambridge University Press, I992)

Kaiser, Cerhard Pietismus und Patriotismus im literarischen Deutschland: Ein Beitrag zum Problem der Säkularisation, 2nd edn (Frankfurt: Athenäum, 1973) zum Prost der Poesie: Heinrich von Kleist Kittler, Wolf, Die Geburt des Partisanen

oxperience, $1789-$ I I 5 (Princeton: Van Nostrand, 1967)

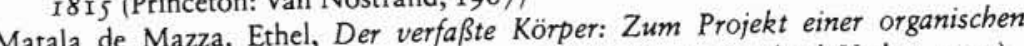
atala de Mazza, Ethel, Der verfaßte Kortik (Freiburg: Rombach Verlag, 1999)

Gemeinschaft in der Politischen Romantik (Freiburg: Rombach Verbarkeit bürgerlichen Geistes, lichen Geistes, Alto, Calif.: Stanford University Press, 2003)

Al Gemeinschaften. Positionen zu einer Philosophie des Politischen (Frankfurt am Main: Suhrkamp, 1994) 